(C) 2016 IEEE. Personal use of this material is permitted. Permission from IEEE must be obtained for all other uses, in any current or future media, including reprinting/republishing this material for advertising or promotional purposes, creating new collective works, for resale or redistribution to servers or lists, or reuse of any copyrighted component of this work in other works. 


\section{Using Games for Teaching Crisis Communication in Higher Education and Training}

Ole Jørgen Ranglund

Faculty of Business Administration

Hedmark University of Applied Sciences

Rena, Norway

Ole.ranglund@hihm.no

Linda Kiønig

Faculty of Business Administration

Hedmark University of Applied Sciences

Rena, Norway

Linda Kiønig@hihm.no

Stig Holen

Faculty of Business Administration Hedmark University of Applied Sciences

Rena, Norway

Stig.holen@hihm.no

Tone Vold

Faculty of Business Administration Hedmark University of Applied Sciences

Rena, Norway

tone.vold@hihm.no

Geir Ove Venemyr

Faculty of Business Administration

Hedmark University of Applied Sciences

Rena, Norway

geir.venemyr@hihm.no

Bjørn Tallak Bakken

Faculty of Business Administration

Hedmark University of Applied Sciences

Rena, Norway

bjorn.bakken@hihm.no

Robin Braun

University of Technology Sydney

Sydney,Australia

robin.braun@uts.edu.au 


\section{ABSTRACT}

Terror actions and catastrophes are frequently described in media. As more and more countries experience terror actions and natural disasters, there has been a greater focus on learning how to handle and to manage them. In Norway on the $\mathbf{2 2}^{\text {nd }}$ of July 2011, Anders Behring Breivik placed a bomb in a car that exploded near the Governmental Offices killing 8 persons. He went on to an island where there was a political camp for youths killing another 67. The rescue operations unveiled an unprepared task force. The Gjørv-report provide a massive critique towards the call out services [1].

This kicked off a major work on updating safety routines in all municipalities. The municipalities are now obliged to have a plan for crisis preparedness [2]. This again triggered the need for education within the area of crisis preparedness, crisis training and crisis management.

Hedmark University of Applied Science now offers different study programs, including a BA within these areas. It is, however, very expensive to train realistically and the need for different approaches regarding training has been discussed. One of the solutions that the University is currently working on, is the use of games.

Game based learning, also called "serious games", has become an academic genre and using games for learning and training has proven fruitful [3-12]. In the military, games have been used for simulation purposes [13] and spin offs from these have also reached a commercial market $[14,15]$.

Using games in education opens up a range of opportunities. One of them is within the area of Crisis Communication. Crisis Communication as a curriculum is about how to approach the area of crisis communication, understanding the key concepts and develop skills within the curriculum.

Games that support communication between the gamers can for instance contribute towards a greater understanding of communication in a crisis situation. What is needed to communicate and how messages are received, in order to support handling a crisis, are amongst the concrete learning objectives one can attribute towards this type of training.

To use games to support the hands on training can thus provide the learners with valuable know how, and support their learning outcome. The learning from this will be beneficial to the organizations they work in as they will have an experience that will aid them in the work on planning for and preparing for crisis in their own organizations.

Keywords: Crisis training; crisis communication; learning objectives; experiential learning; games based learning; serious games

\section{INTRODUCTION}

Learning about crisis and about how to handle them has become increasingly important due to the recent terror actions. Even in Norway we have experienced terror actions that shook the nation. As a consequence the government has decided to introduce regulations requiring that all municipalities must have a plan of action regarding crisis management [2].

Hedmark University of Applied Sciences has developed a Bachelor in Crisis Management to meet the demand that came as a consequence of the regulations. The study provides the students with courses in for example crisis management and crisis communication. The students do however miss experiences and as exercises where they could train are expensive and require planning and facilities, the idea about simulations and games occurred.

It was decided to test out a gamebased simulation for use in the study in order to introduce an opportunity for the students to get more experiences without setting up expensive exercises.

The game in use is based on Virtual Battlespace (VBS) which was developed with influence from a war game called Operation Flashpoint from 2000. VBS 1 was developed in 2001. When the American Marine Core took interest in the project, it was invested heavily towards the end of 2001 to develop the game further $[15,16]$.

The script for the game play is developed by lecturers at Hedmark University of Applied Science together with five students attending the Bachelor in Crisis Management.

The students have some experience in rescue operations as some of them work as volunteers in the Norwegian Red Cross.

The paper explores the testing of a serious game for learning about crisis management and crisis communication. Firstly we present the theoretical backdrop and the reasoning for using serious games. Then we present how we collected our data from the project before we discuss the results from the analysis. Lastly we conclude and provide our suggestions of how we can take this further.

\section{THEORETICAL BACKDROP}

Games for learning or "Serious games" has been around for a few years now and the potential for them are growing as the technology is developing rapidly.

Most important is to maintain the balance between keeping game play fun and engaging on the one side and making sure it has a pedagogical value on the other side [13].

A game is defined by K. Salen and E. Zimmerman as: "A game is a system in which players engage in an artificial conflict, defined by rules, that results in a quantifiable 
outcome"[17]. The engagement starts when entering "the magic circle" $[17,18]$ which is a mental state. When adding "to much" pedagogy, it is easy to fall out of this magic circle and thus loose the engagement in the game[19].

The learning from a game is, however, the reasoning for using the game in the education. It is thus important to make sure that the learning outcome is maximized. What we want to obtain is experiential learning, and what is described in David A. Kolb's experiential learning circle [20]: The first gameplay provides an experience that one can reflect upon, and then it is possible to find different solutions and decide upon the basis for the next experimentation. This implies that the student themselves are able to influence the next gameplay. This involvement by the learner can lead to increased engagement $[21,22]$. This way of organizing also allow for the students to contribute based on their own experiences, which is what John Dewey advocates [23].

\section{Concrete}

\section{Experience}

(doing / having an experience)

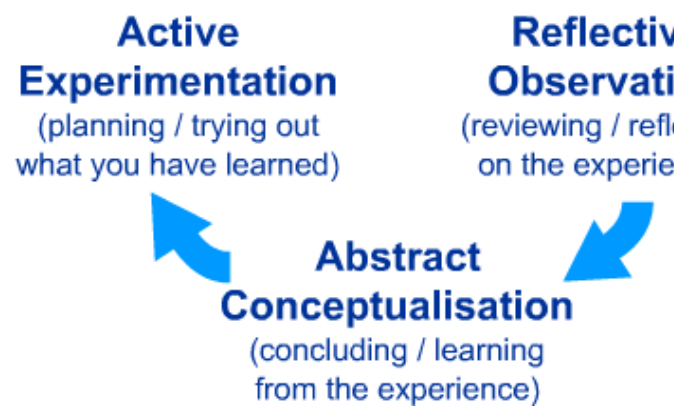

Figure 1 The experiential learning cycle[24].

The experiential learning cycle also describes reflection, which is essential to learning. Donald A. Schön has described how one learns from reflecting upon action [25, 26]. Also to reflect upon action when in action should be encouraged. To organize reflection during gameplay can be done by one or several "time out's". It is, however, important not to break the flow that may emerge during the gaming session [27]. We want to achieve the state of flow in order to support the creative processes [28].

Reflection can also be undertaken after the gaming session. This may resemble after action review that is used in the military to learn from actions undertaken during an exercises[29].

Since the focus is on learning and the learning is to be what they bring back to their organization it is possible to look at how adults learn in organizations. To be involved and to use one's own experiences, to learn in a community and discussing with peers are some of the main features of adult organizational learning [30, 31]. For the gaming session it is possible to discuss with peers and cooperate and co-produce solutions with peers. Also letting the students contribute towards the script for the game play can be a way of including the students in order to support and facilitate for engagement and ownership to the process [32-34].

\section{METHOD OF INQUIRY}

In order to collect data regarding how the students perceived using a game and also contribute towards development of the game, we used interviews, both structured and unstructured with interview guides [35-38]. We also used field notes that were based upon our observations from the gaming sessions [39]. We also asked the students to send us their own reflections from the gaming sessions. The data were divided into two main sections: a)how the students perceived the learning outcome from the gaming sessions, b) how being involved in the development process contributed towards their learning process.

Due to our interest about the topic and our biases regarding introducing games as a tool for learning it was important to take this into consideration when searching the data sets for valid information.

In order to secure the data we did extensive "member checking" in order to make sure that we had valid data [40].

\section{RESULTS AND ANALYSIS}

The outcome was nearly as expected. There were some technical issues regarding the software, as some of the avatars did not respond as foreseen in the game. However, this turned out to be minor details.

We have divided the results into two subsections; Learning from gaming, and Learning from Development.

\section{1) Learning from Gaming}

Even if there were some minor issues with the software, the students clearly state the potential that lye in this gaming. Since it is possible to play two groups "against" each other (one group playing the rescue team and another play the managers of the rescue operation), it is possible to train for different roles. The gaming clearly showed the importance of communication as a tool for obtaining the proper rescue procedures and for the avatars to conduct the rescue operations.

Crisis Communication is thus amongst the features the students point at regarding learning outcome.

However, for some of the students the gameplay was extremely difficult to keep track of and the multitude of actions going on. Being confused may obstruct the learning process [41] and this gave us valuable input towards leveling based on previous gaming experience. Low level of gaming experience implies a level with fewer incidents and factors to 
pay attention to. As "the gamers" increases their skills, it is possible to add more factors and thus increase the level.

\section{2) Learning from Developing}

The students also claim to have learned from developing the scenario. Based on their backgrounds from rescue operations, they were able to contribute towards the development of the scenario to be tested and played. This they report to having been important to their learning process as they now were able to see the incidents from a different perspective. They also saw the potential of testing out scenarios they knew well and needed to see if could have other outcomes. This refers to Donald Schön and his "reflective practitioners" [25, 26] as this can be viewed as a way of reflecting over practice. It can also be related to David A. Kolb and his "experiential learning cycle" [20, 42] where the experiencing can be the real life experience, the reflection is the reflection upon the real life experience, the abstraction is about developing the new scenario based on the real life experience and the new experiencing can be the gaming sessions which again will provide the student with a new experience.

Also to base the learning on previous experiences is what John Dewey recommends [23, 43, 44] as this will motivate the students due to its apparent relevance.

To base cases and to tie curriculum to the students own experiences is also used in other degrees and courses at Hedmark University of Applied Sciences. For instance, in the courses "Learning Organizations" and "Knowledge Management", it has become increasingly important to include the students in the development of the cases in order to make them relevant to the students. This motivates the students to contribute and enhances the learning process [45].

\section{CONCLUSION AND FURTHER RESEARCH}

The game seems to embrace both learning as well as maintaining the gameplay and keep the students within "the magic circle". According to the students they do learn from the gaming. And not only do they learn from the gaming they also learn from contributing towards the development of the script for the gaming.

The game technology still need some work in order to support a better "real life" experience, but does, even with the minor flaws. The students seem to be emerged in the game, and they are able to reflect upon actions within the gaming.

\section{1) Further research}

The next step is to involve more students. As soon as the technical issues are resolved, it will be implemented in the course Crisis Communication and we will facilitate for student involvement in the development of the scripts for the gaming sessions in order to test this on a larger group. This needs careful planning to avoid misunderstandings that lead to confusion that in turn will prohibit learning [41]. Also the idea of student contribution towards script is probably something that is not widely used so this needs careful introduction [46]. There is however little doubt that this game will be an important contribution towards a study that provide more experiencing and can be an important contribution alongside costly exercises.

\section{ACKNOWLEDGEMENTS}

We would like to thank Henrik Klevhus, Anders Klevhus and Petter Granlien. They are the students that have contributed towards this research as they have undertaken this work beside their "ordinary" studies. They have shown a particular engagement, and their ideas and contributions have been particularly valuable towards the research for this paper.

\section{REFERENCES}

[1] A. B. Gjørv. (2012). Rapport fra 22. julikommisjonen : oppnevnt ved kongelig resolusjon 12. august 2011 for å gjennomgå og trekke lardom fra angrepene på regjeringskvartalet og Utфya 22. juli 2011. Avgitt til statsministeren 13. august 2012. NOU 2012:14.

[2] D. f. s. o. b. (DSB), "VEILEDNING til forskrift om kommunal beredskapsplikt," D. f. s. o. b. (DSB), Ed., ed: Direktoratet for samfunnssikkerhet og beredskap (DSB), 2012.

[3] C. Aldrich, Simulations and the future of learning: an innovative (and perhaps revolutionary) approach to e-learning. San Francisco: Pfeiffer, 2004.

[4] D. Clark, "Games, Motivation \& Learning," ed: Caspian Learning, 2007, p. 22.

[5] C. N. Quinn, "Computer-based Simulations Principles of Engagement," in The Handbook of Experiential Learning, M. Silberman, Ed., ed San Francisco: Pfeiffer, 2007, pp. 138-154.

[6] C. N. Quinn, Engaging Learning: Designing eLearning Simulation Games. San Francisco, CA: Pfeiffer, 2005.

[7] J. P. Gee, What Video Games Have To Teach Us About Learning And Literacy. New York: Palgrave MacMillan, 2003.

[8] J. P. Gee, Situated language and learning: a critique of traditional schooling. London: Routledge, 2004.

[9] J. P. Gee, Good Video Games + Good Learning. New York: Peter Lang Publishin, Inc., 2007.

[10] S. Egenfeldt-Nielsen, "Overview of research on the educational use of videogames," Digital Kompetanse, vol. 1, pp. 184-213, 2006.

[11] S. Egenfeldt-Nielsen, Educational potential af computer games. London: Continuum, 2007.

[12] T. Vold and S. McCallum, "Gamers and learning," in 10th International Conference on Information Technology Based Higher Education and Training, Kusadasi, Turkey, 2011, pp. 1-4. 
[13] B. Bergeron, Developing Serious Games. Hingham: Charles River Media, Inc, 2006.

[14] ESimGames. (2012, 2005). eSimGames. Available: http://www.esimgames.com/

[15] BohemiaInteractiveSimulations. (2010, 04.06.). Bohemia Interactive Simulations [Web page]. Available: http://www.bisimulations.com/

[16] BohemiaInteractiveSimulations. (2016, 29.04.). BohemiaInteractiveSimulations [web page]. Available: https://bisimulations.com/

[17] K. Salen and E. Zimmermann, Rules of Play: Game Design Fundamentals. Cambridge, Mass.: MIT Press, 2004.

[18] R. Linser, N. Ree-Lindstad, and T. Vold, "The Magic Circle - Game Design Principles and Online Roleplay Simulations," ed. Melbourne: Fablusi P/L, 2007.

[19] R. Linser, N. Ree-Lindstad, and T. Vold, "Black Blizzard - Designing Role-play Simulations for Education," in 7th International Educational Technology Conference, Near East University, Nicosia, North Cyprus, 2007.

[20] D. A. Kolb, Experiential learning: experience as the source of learning and development. Englewood Cliffs, N.J.: Prentice-Hall, 1984.

[21] J. Mezirow, Learning as transformation: critical perspectives on a theory in progress. San Fransisco: Jossey-Bass, 2000.

[22] D. Michael and S. Chen, Serious Games: Games That Educate, Train and Inform. Boston, MA: Thomson Course Technology PTR, 2006.

[23] J. Dewey, Experience \& Education. New York: Touchstone, 1938.

[24] C. Davies. (30.08.). Kolb Learning Cycle Tutorial Static Version [web page]. Available: http://www.ldu.leeds.ac.uk/ldu/sddu_multimedia/kol b/static version.php

[25] D. A. Schön, Educating the reflective practitioner. San Francisco, Calif.: Jossey-Bass, 1987.

[26] D. A. Schön, The reflective practitioner : how professionals think in action. Aldershot: Avesbury, 1991.

[27] M. Csikszentmihalyi, Flow: The Pshychology of Optimal Experience. New York Harper \& Row, 1990.

[28] M. Csikszentmihalyi, Creativity: flow and the psychology of discovery and invention. New York: HarperCollins, 1996.

[29] D. von der Oelsnitz and M. W. Busch, "Teamlernen durch After Action Review," Personalführung, pp. 54-62, 2006.

[30] E. J. Irgens, Dynamiske og larende organisasjoner : ledelse og utvikling $i$ et arbeidsliv $i$ endring. Bergen: Fagbokforl., 2011.

[31] C. Filstad and G. Blåka, Learning in organizations. Oslo: Cappelen, 2007.
[32] A. A. Bechina and T. Vold, The Participatory Roles Play Simulation in a Social and Collective Learning Context: Springer Berlin Heidelberg, 2012.

[33] T. Vold and S. Yildirim-Yayilgan, "Playful Participation in Higher Education - The introduction of participatory role play simulation in a course at Hedmark University College," in ITHET 2013, Antalya, Turkey, 2013.

[34] T. Vold, S. Yildirim-Yayilgan, and J. Sørnes, "New Takes on Learning in Organizations When Using Role Play Simulation," presented at the European Conference on Knowledge Management, Santarem, Portugal, 2014.

[35] J. W. Creswell, Research Design: Qualitative, Quantitative, and Mixed Methods Approaches, 2nd ed. Thousand Oaks: Sage Publications, Inc, 2003.

[36] M. B. Postholm, Kvalitativ metode: en innføring med fokus på fenomenologi, etnografi og kasusstudier. Oslo: Universitetsforl., 2010.

[37] N. K. Denzin and Y. S. Lincoln, The Sage handbook of qualitative research. Thousand Oaks, Calif.: Sage, 2005.

[38] M. Dalen, Intervju som forskningsmetode. Oslo: Universitetsforl., 2011.

[39] K. Fangen, "Analyse av observasjonsdata," in Deltakende observasjon, K. Fangen, Ed., ed Oslo: Fagbokforlaget, 2004, pp. 170 - 194.

[40] E. G. Guba and Y. S. Lincoln, Fourth generation evaluation. Newbury Park, Calif.: Sage, 1989.

[41] D. Kember, A. Jones, A. Loke, J. McKay, K. Sinclair, H. Tse, et al., "Determining the level of reflective thinking from students' written journals using a coding scheme based on the work of Mezirow," International Journal of Lifelong Education, vol. 18, pp. 18-30, 1999.

[42] K. Illeris, "The Development of a Comprehensive and Coherent Theory of Learning," European Journal of Education, vol. 50, pp. 29-40, 2015.

[43] J. Dewey, Democracy and Education: Barnes \& Noble Books, 2005.

[44] J. Dewey and A. F. Bentley, Knowing and the Known. Boston Beacon Press, 1949.

[45] T. Vold, "How Can the Concept of "Flipped Classroom" Support the Development of Reflective Practitioners in Higher Education? ," in ITHET2014, York, UK, 2014.

[46] T. Vold, S. Yildirim-Yayilgan, and J. Sørnes, "New Takes on Learning in Organizations When Using Role Play Simulation

" in ECKM 2014, Santarem, Portugal, 2014. 
